\title{
Metalloproteinases involvement in liver tumoral pathology- an update
}

\author{
Elena-Roxana Avădănei*, Simona-Eliza Giușcă, Irina-Draga Căruntu, Cornelia \\ Amălinei
}

Department of Morphofunctional Sciences, "Grigore T. Popa" University of Medicine and Pharmacy lasi, Romania

\begin{abstract}
MMPs and TIMPs involvement in tissue destruction may be incriminated in malignant invasion and metastasis, showing correlations between the overexpression, aggressiveness, tumor stage and prognosis. Recent data provide evidence of their complex role in creating an auspicious microenvironment for tumor growth in primary and metastatic sites. The investigation of MMPs and TIMPs functional interdependency is an important direction, useful in carcinogenesis intrinsic mechanisms deciphering, its apparently paradoxical role being incompletely defined. Literature review regarding MMPs and TIMPs study in primary and secondary hepatic tumors allows us to affirm that defining a precise profile of their activities is extremely difficult. The most studied metalloproteinase, in liver tumoral microenvironment, were MMP2 and MMP9 together with their inhibitors TIMP 2 and TIMP1, respectively. The expression variability of both MMPs and TIMPs is associated to promoter or inhibitor action of stromal cells and / or tumor cells, as liver microenvironment has a modulatory action for MMPs and TIMPs. MMPs capacity to intervene in many biological processes is attributed to their ability of ECM proteolysis, as a possible initiator of unrevealed functions. The understanding of biochemical and structural aspects of MMPs, and the capacity to form molecular complexes with TIMPs open the perspectives of design of potent specific inhibitors for MMPs and, thus, the development of new therapies for primary and metastatic liver cancers.
\end{abstract}

Keywords: matrix metalloproteinases (MMPs), tissue inhibitors of metalloproteinases (TIMPs), HCC, liver metastasis, carcinogenesis.

\section{Introduction}

Tumor microenvironment is a continuously changing concept in defining malignant behavior not only by genetic mutations but also in the cellular and molecular context of their particular medium which provides cells

Received: August 2015; Accepted after review: August 2015; Published: September 2015.

*Corresponding author: Elena-Roxana Avădănei, MD, PhD, Discipline of Histology, Department of Morphofunctional Sciences, "Grigore T. Popa" University of Medicine and Pharmacy, 16 University Street, 700115 lasi, Romania;

E-mail: roxanavadanei@yahoo.com the opportunities for growth, proliferation, and/or metastasation [1, 2].

Tumor microenvironment is a dynamic system, mostly orchestrated by inflammatory cells, including: (i) cellular component represented by tumor cells, immune cells: $T$ cytotoxic and regulatory cells, fibroblasts, myofibroblasts, macrophages, and endothelial cells; (ii) a non-cellular component represented by growth factors, such as TGF- $\beta$ and PDGF, proteolytic enzymes, such as matrix metalloproteinases (MMPs) and their specific inhibitors (TIMPs), extracellular matrix proteins $(\mathrm{ECM})$, and inflammatory cytokines [3-5]; all these elements form a cellular and 
molecular complex in a continuous functional interrelation $[5,6]$.

Recent studies highlight the microenvironment role in initiation, onset, and development of primary and secondary liver cancer, firstly reflecting the direct relationship between the chronic inflammatory status generated by $\mathrm{B}$ and $\mathrm{C}$ viruses, by production of cytokines and growth factors, and the appearance of carcinogenic process $[4,5]$.

Macroregenerative nodules of cirrhotic liver contain foci of dysplastic hepatocytes. Histologically, these dysplastic lesions are classified: "with small cells", "with large cells", and "adenomatous hyperplasia foci"; between these, dysplastic lesions with small cells and adenomatous hyperplastic lesions are considered as precursor lesions of hepatocellular carcinoma (HCC) [7].

Liver malignancies represent the fifth most frequent type of cancer and the third cause of death worldwide [8]. HCC is the most common liver cancer in adult representing more than $90 \%$ of all primary liver cancers [9]. The majority of patients diagnosed with HCC have a background chronic inflammatory disease this being considered the main cause of primary liver tumor.

The general accepted paradigm related to carcinogenesis is that the malignant transformation is produced by the progressive accumulation of genetic and epigenetic alterations which result in malignant phenotype achievement. On the other hand, recent studies have launched the idea of a minimum number of molecular changes responsible for the acquisition of a key characteristic of malignant phenotype, such as, among others, unrestricted cellular proliferation [10, 11].

The lack of understanding of intimate substrate and of a clear delimitation of some steps in hepatic carcinogenesis may be partially attributed to tumor profile versatility; this might be initiated in variable genetic and medium contexts and almost sure developed due to denaturation the regulatory action of some signaling pathways [12]. In a complete scenario of pathogenesis, this limitation restrains the development of some efficient interventions, regarding prevention or therapy.
Recent analyses using genomic approaches and improved animal models tried new and promising subclassification of the largely heterogeneous molecular and prognosis tumor subtypes $[13,14]$.

\section{About the MMP Family}

Matrix degrading metalloenzymes, matrixins or matrix metalloproteinases, metalloproteinases (MMPs) [15-18] are part of a multigenic family of proteolytic enzymes, firstly described half century ago [19], functioning at neutral $\mathrm{pH}$ [20] which are present in hepatic microenvironment. MMPs are produced in their latent form, as proenzymes (inactive zymogens) or pro-MMPs and, thus, require a process of proteolytic activation [21].

Matrix metalloproteinases (MMPs) family consists of endopeptidases that share homologous protein sequences, being composed of conserved domains and specific domains [20]. Their great variability results in their complex intervention in large panel of pathophysiological conditions. MMPs display a key role in embryogenesis and in a large spectrum of physiological activities, such as cell motility, proliferation, remodeling, healing, angiogenesis, and reproductive events [2225].

MMPs activity is closely regulated by their endogenous inhibitors, tissue inhibitors of MMPs (TIMPs) [21]. MMP / TIMP imbalance may result various inflammatory, neoplastic, and degenerative conditions $[18,26]$.

Due to structural and substrate specificity, MMPs are currently divided into seven classes: collagenases (MMP1, MMP8, MMP13, and MMP18), gelatinases (MMP2 and MMP9), stromelysins (MMP3, MMP10), stromelysin like (MMP11 and MMP12), matrilysins (MMP7 and MMP26), membrane type (MMP14, MMP15, MMP16, MMP17, MMP24, and MMP25), and others (MMP19, MMP20, MMP21, MMP22, MMP23, MMP27, and MMP28) [18, 27, 28].

ADAM family proteinases (a disintegrin and metalloproteinase) and ADAMTS (a disintegrin and metalloproteinase with thrombospondin motifs) are also associated, 
being involved in a large spectrum of activities, such as fertilization, development, and carcinogenesis [29].

MMPs tissue inhibitors (TIMPs) belong to a family of multifunctional molecules $[30,31]$ which act as specific endogenous MMPs regulators, expressing an important role in adaptive modulation of ECM by their action on cellular adhesion molecules, cytokines, chemokines, and growth factors [31].

There are 4 known members of TIMPs family, able to inhibit all known MMPs [30, 32, 33], however their inhibitory action is variable for each member in correlation to MMPs substrate. For instance, TIMP1 strongly inhibits many MMPs excepting membranar type, including MMP14,-15,-16,-19 and -24 [30, 32]. TIMP1 and TIMP3 inhibitory activity register latency in correlation to MMP9, while TIMP2, -3 and -4 are able to interact even with pro-MMP2 [32, 34].

TIMP1 overexpression is associated with a significant reduction of degradative capacity of mesangial cells on the matrix while the addition of a neutralizing anti-TIMP1 antibody results in increased matrix degradation ability $[34,35]$.

The known literature data are demonstrating the protective ECM role of TIMP2 for excessive proteolytic effects seen in some fractures [36], keloids [37], hepatic lesions [38, 39], kidney [40], Dupuytren contractures [41], and heart lesions [42].

TIMP3 has more variable functions, including inflammation regulation by ADAM17 inhibition [43]. There are powerful proofs correlated to its function, suggesting that TIMP3 is a key inhibitor in ECM remodeling [34].

TIMP4 prevents ECM proteolysis in lungs [44], female genital tract, [45], eyes [46], and in transplanted tissues [47].

The investigation of MMPs and TIMPs functional interdependency is an important direction, useful in carcinogenesis intrinsic mechanisms deciphering, its apparently paradoxical role being incompletely defined [30].

MMPs intervene in tumor genesis and invasiveness by their powerful proteolytic action on ECM, initially demonstrated by in vitro experiments [48]. Beside their ECM degradation role, MMPs possess other biological roles, such as; promoter of tumor cells, proliferation stimulator, apoptosis inhibitor, pro- and antiangiogenic action [4951]. Numerous researcher teams have demonstrated a direct association between their action and tumors development [23, 52].

MMPs are overexpressed in large spectrum of human malignant tumors, including cutaneous [53], colorectal [54], breast, lung and prostate [55-57], esophagus [58], stomach [59, 60], endometrial [61], and ovarian [62]. Occasional controversial reports are supported by other authors [63].

MMPs and TIMPs expression evaluation is mainly focused on stromal cells and less on tumor cells. MMPs and TIMPs are largely produced by reactive stromal cells previously recruited in tumor microenvironment [64]. As a response to microenvironment stimuli, stromal cells develop secretory capacities [65]. MMPs, together with cysteine proteinases, aspartic proteinases, and serine proteinases are proteolytic enzymes involved in extracellular matrix (ECM) and basement membranes (BMs) degradation [66].

For instance, MMP9 involvement in collagen IV degradation, resulting in basement membrane loss of integrity, is well known [52]. As a consequence of its activation and basement membrane degradation favors metastatic process, supplemented by amplification of vascular permeability, as powerful machinery of matrix degradation [48]. The correlation between MMPs and TIMPs proved to be a useful tool in prognosis evaluation.

\section{Overview of MMPs and TIMPs in tumoral pathology}

MMPs involvement in tissue destruction may be incriminated in malignant invasion and metastasis [20], showing correlations between the overexpression, aggressiveness, tumor stage and prognosis [67], periodontitis, bullous dermatitis, osteoarthritis, chronic ulcers, nephritis [66], photo aging, fibrosis, endometriosis [18, 26], osteoarthritis, rheumatoid arthritis, [68,69], decubitus ulcer, 
gastric ulcer [70], corneal ulceration, brain injury [71], and neuroinflammatory diseases [72]. MMPs have been variably associated to atherosclerosis, fibrotic lung disease, liver cirrhosis, otosclerosis, and multiple sclerosis [73]. Furthermore, MMPs have been considered as important players in weakening of the matrix, as in aortic aneurysm [74], dilated cardiomyopathy, epidermolysis bullosa, and restenotic lesions [75].

\section{MMPs involvement in tumor invasion and metastasis}

Although the mechanism of degradation of extracellular matrix involved in tumor invasion and by default in circulation intravasation, extravasation and migration to metastatic sites [76] has been initially considered, recent data provide evidence of their complex role in creating an auspicious microenvironment for tumor growth in primary and metastatic sites [67]. Removal of ectodomains in the pericellular space, by cleavage of a transmembrane molecule in the juxtamembrane region of the extracellular domain, alters the signaling on the cell surface, a mechanism involved in tumor proliferation and angiogenesis. Thus, HB-EGF is removed by MMP3 and MMP7 in tumor proliferation and angiogenesis, E-cadherin by MMP3 and MMP7, in tumor invasion, and TNF- $\alpha$ by MMP7, in tumor apoptosis [67].

By the release of soluble E-cadherin, a transmembrane cell adhesion protein, the inhibition of MMP3 and MMP7 is carried out, in a paracrine manner, acting as a promoter of the migration and invasion [77]. MMP7 converts the activator of nuclear factor kappa $B$ ligand receptor (RANKL) in a soluble form that promotes osteoclast activation in metastatic prostate cancer [78]. Experiments with transgenic mice show complex and somewhat paradoxical effects of MMP system in tumor carcinogenesis. Experiments which dosed the levels of TIMP1 and TIMP2 production, demonstrate high levels of TIMP1 in all cancerous tissues [79]. Imbalance between MMPs (MMP1, MMP2, MMP3, MMP7, MMP8, MMP9, and MMP13), TIMP1 and TIMP2 was found with no correlation between the molar ratio and cancer progression or metastasis [79]. TIMP-1 can act as a growth promoter and / or antiapoptotic factor for cancer cells [80].

\section{MMPs interaction with non-extracellular matrix proteins in tumor invasion}

Although extracellular matrix degradation has been considered as the main MMPs mechanism of involvement in tumor invasion, followed by intravasation into circulation, extravasation, and migration to metastatic sites [76]. Cytokines, growth factors, and cell adhesion molecules exhibit a complex control on MMPs. MMP3, MMP7, MMP9, and MMP19 stimulate tumor growth by releasing IGF (insulin-like growth factor) [20].

The process of invasiveness in tumors has been attributed to fibroblasts enzymes [81] and subsequently isolated and identified as serine proteinases, hyaluronidases, and MMPs. MMPs are responsible for stimulation of neoangiogenesis [23], for tissue breakdown and remodeling, followed by intravasation into circulation, extravasation, and metastasis to distant sites [82]. Consequently, MMPs are overexpressed in a wide panel of tumors in correlation to their stage, aggressiveness, and prognosis [20].

MMP expression seems to be more complex than simple tumoral cell secretion, being characterized by metalloproteinase expression induction in "host" stromal cells [83], corresponding also to the fibroblastic population described in the original postulate [81].

MMP9 overexpression in tumor cells induced by oncogene products, growth factors, and cytokines and loss of the metastatic phenotype due to its inhibition, lead to the concept of MMP9 key role in the invasion and metastatic processes [84]. The activation ratios of pro-MMP2 correlate with lymph node metastasis in lung, breast, thyroid, and digestive tract carcinomas [79]. Moreover, proMMP2 overexpressed in stromal fibroblasts or serum derived is captured and activated on the surface of cancer cells by MT1-MMP. Thus, MT1-MMP overexpression is correlated to that of MMP2 in carcinomas [79]. As TIMP2 
is required for the efficient activation of proMMP2 by MT1-MMP, immunohistochemistry [79] and in situ zymography [79] demonstrated their co-localization in epithelial carcinomatous and adjacent stromal cells.

The principal role of ECM degradation by tumor-derived proteases has been recently enhanced by profound effects on cell adhesion and migration related to gelatinase $A$ activation on various tissue culture substrates including gelatin, fibronection, and vitronectin [85]. Inhibition of the endogenous gelatinase A with either neutralizing antibody or TIMP2 in these cultures results in enhanced attachment to these substrates. The altered production of TIMP2 modulates ECM proteolysis, cell adhesive and spreading properties, resulting in modified cell morphology.

MMP2 promotes the migration of breast malignant carcinomatous cells by cleaving and regulating laminin-5 (Ln-5), as a specific ECM glycoprotein [86]. Tumoral cells adhere or migrate on BM components, such as collagen type IV, fibronectin, and laminin-1 [87, 88], using integrin receptors [32]. The Ln-5 subunit is cleaved by collagenase $A$ at residue 587 , exposing a putative cryptic pro-migratory site or may mask a site that suppresses cell motility. The pro-motility cryptic site does not support adhesion suggesting that the gelatinase A proteolytic activity may provide a signaling mechanism for tumoral cells. Consequently, migration is initiated during mammary gland morphogenesis or tumorigenesis, as demonstrated by an enhanced migratory response to gelatinase $A$, in the breast carcinomatous cell line, MCF-7 [89].

An excessive proteolysis impairs tumor cell adhesion or disrupts and degrades the cell-matrix interactions or matrix signals required for migration and invasion, suggesting a critical range or gelatinase A / TIMP2 ratio necessary for tumor invasion and angiogenesis [90]. A correlation between gelatinase A overexpression and tumor grade, in carcinomas of the colon, prostate, bladder, pancreas [91], breast, ovary, and skin (squamous and basal cell histological types) has been demonstrated in numerous experimental studies. MT5-MMP activates pro-
MMP2, exhibiting a strong expression in brain tumors [92].

The expression of both MMPs and their specific TIMPs has been associated to tumor progression and clinical outcome, exhibiting an increased level of TIMPs in malignant tissues [79]. Thus, antiapoptotic and/or growth promotor capacities have been attributed to TIMP1 [80]. An enhanced expression of gelatinase $B$ mRNA has been associated to an early relapse and poor survival [93] and a strong TIMP1 expression has been correlated to metastatic spread and an early relapse in colorectal cancer [94].

Similarly, other MMPs or TIMPs have been associated to poor prognosis in malignancies with different locations, as following: activated gelatinase $A$ in stomach [95], stromelysin-3 in breast [96], TIMP1 in lung (small cell type) [97], and TIMP2 in bladder [98].

The high level of regulatory activity associated to an amplified metalloproteinase expression results in both a high expression of MMP and the specific inhibitor. Local remodeling, by angiogenesis and stromal tissue transformation is generated by interaction between MMPs and TIMPs produced by the tumor cells and microenvironment.

Collagenases, gelatinases, stromelysin-3, matrilysin, MT1-MMP [99], and stromelysin-1 [100] are considered the most closely associated to the invasive phenotype. The mechanism of tumor progression promotion is performed by MMPs by disrupting local tissue architecture, by stimulation growth via angiogenesis, and disrupting the basement membranes to allow metastatic spread. The tumoral cells produce collagenase-3, gelatinase $A$, and matrilysin, while most other MMPs are produced by stromal host cells stimulated by tumoral cytokines. For example, gelatinase A binds to endothelial cell, promoting tumor angiogenesis [101].

The efficacy of MMP inhibitors is highly variable, more efficient in nude mice models and less efficient in case of numerous tumor associated macrophages, possible as a property of macrophage elastase. Macrophage elastase is exclusively expressed in host 
macrophages, as demonstrated in human breast cancer [102]. Moreover, macrophage elastase is responsible for dormancy status of lung metastases in murine models of lung cell carcinoma [103].

Consequently, macrophage elastase prevents metastatic growth, while other MMPs are tumoral promoters. MMPs interact with endothelial cells, promoting tumor angiogenesis. Oppositely, macrophage elastase produced by tumor-associated macrophages cleaves plasminogen, thrombospondin, and type XVIII collagen generating anti-angiogenic molecules, such as angiostatin, thrombospondin fragments, and endostatin, respectively. Macrophage elastase expresses a higher binding affinity for elastin and other matrix components than other MMPs and consequently may have more potent proteolytic capacity. Moreover, the free C terminal of metalloellastase competes for endothelial cell binding with "pro-angiogenic" MMPs [104].

MMP expression in tumor and stromal cells is tumor-type dependent [90]. MMP3 is expressed in tumoral stroma of invasive breast cancer along with MT1-MMP, MMP1, MMP2, and MMP11 [105]. MMP9, MMP12, and MMP13 have a focal location: endothelial cells MMP9 expression, isolated tumor cells MMP13 association, and macrophage-like cells MMP12 expression [105]. MMP1, MMP3, MMP7, and MMP10 are expressed by head and neck carcinoma. MMP2 and MMP3 are expressed by squamous cell carcinomas of esophagus. MMP7 is expressed by colon and gastric carcinomas and MMP3 is produced by stromal component of some colorectal carcinomas. The normal mucosa adjacent to bronchial lesions, intraepithelial lesions, and squamous carcinomas of the lung express MMP3 transcripts [90], while a primarily MMP3 expression is observed in microinvasive and invasive bronchial lesions.

The correlation between invasive tumoral behavior and the expression of stromelysins is suggested by variable MMP3 and MMP10 expression in transformed rat embryo cell lines. The isolated expression of a single matrixin, MMP3, is insufficient for the progression to an invasive and metastatic breast cancer phenotype, in transgenic mice models but the process is amplified by the matrix degradation resulting in cell proliferation and apoptosis alteration [90].

Progelatinase $A$ is activated by forming a trimeric complex with MT1-MMP and TIMP2 [106]. TIMP2 may inhibit the cell surface activation of progelatinase $A$ or facilitates progelatinase $A$ binding to the cell surface by progelatinase A-TIMP2 complex formation. The variable ability of tumor cell lines to bind progelatinase $A$ with or without enzyme activation suggests the presence of a progelatinase A receptor distinct from MT1MMP receptor, such as integrin $\alpha v \beta 3$ of the surface of cultured melanoma cells [101].

An excess TIMP2 over the levels of gelatinase A-TIMP2 complex in the culture fluid of many human tumor cells from melanoma, fibrosarcoma, breast carcinoma, lung carcinoma, and pancreatic carcinoma was observed in sensitive and specific sandwich ELISAs [90]. The great variability of secreted TIMP2 / gelatinase A ratio in culture may have a variable influence on the invasive behavior of tumor cells. The progelatinase ATIMP2 complex has to be activated, as most of the progelatinase A produced by cells is immediately complexed with TIMP2.

A positive cells and a lower percentage of TIMP2 positive cells were found in final stages of gastric cancers compared to survivors.

The mean gelatinase A / TIMP2 ratio in patients with recurrent urothelial cancer showing muscular invasion or lymph node metastasis is significantly higher than in patients without recurrence [107]. The disease-free survival is inversely correlated to gelatinase A: TIMP2 ratio [107]. The gelatinase A / TIMP2 ratio measured by RTPCR suggests enhanced gelatinase $A$ expression relative to TIMP2 in patients with lymph-node metastasis of breast cancers [108], without correlation between the magnitude of this ratio and the frequency of positive lymph nodes or to relapse status. Thus, an early prognostic indicator in various types of human cancer may be obtained by evaluation of gelatinase A / TIMP2 mRNA balance and/or serum level. 
MMP3 and MMP7 capacity to release soluble E-cadherin, a cell adhesion transmembrane protein, results in paracrine inhibition of its function and consequently acting as a promoter of tumor cell migration and invasion.

MMP7 promotes the osteoclast activation mechanism in metastatic prostate cancer due to its ability to transform the receptor activator of RANKL (nuclear factor-kappa B ligand) to a soluble form [78].

MMPs exhibit complex and somehow paradoxical effects in carcinogenesis, as demonstrated by transgenic or knock-out mice experiments. Haptoglobin-MMP1 stimulates hyperkeratosis and acanthosis, promoting skin carcinogenesis, a process enhanced by MMP8 absence in defective inflammatory responses, and inhibited MMP9 absence (a mechanism involved in prolonged contact dermatitis) [23, 109, 110]. MMP3 involvement in epithelial cell apoptosis and MMP14 in breast hyperplastic processes stimulate breast carcinogenesis. Due to MMP11 involvement in neoangiogenesis, its absence results in breast carcinogenesis inhibition and similarly pancreatic carcinogenesis is reduced by the lack of MMP2 and by of MMP9 [23, 109, 110]. MMP2, MMP7, MMP11 absence results in carcinogenesis inhibition; the lack of MMP9 results in reduced metastatic process and MMP-11 absence stimulates the metastatic mechanism [23, 109, 110]. MT4-MMP has an unknown mechanism of involvement in breast carcinoma, being also expressed in breast cancer cell lines.

\section{MMPs involvement in tumor angiogenesis}

Angiogenesis anomalies occur in many pathological processes, such as rheumatoid arthritis, diabetic retinopathy, psoriasis, hemangiomas and cancer [111]. MMP2 causes cleavage of collagen IV, by engaging the PEX domain, to expose cryptic sites av $\beta 3$ (by coupling loss to integrin $\alpha 1 \beta 1$ that promotes tumor angiogenesis) [111]. MMP2, MMP9, MMP7 are expressed in tumor endothelial vascular cells [111]. Additionally, MMP7 stimulates the vascular proliferation [111]. Conversely, oligonucleotides anti- matrilysin inhibits tumor angiogenesis [111]. Generation of MMP9 in macrophages and tumor endothelial cells opens new perspectives for correlations between MMPs [23]. MMP9 can generate tumstatin by proteolysis of collagen IV, with suppression of angiogenesis and tumor growth [23].

MMPs are necessary for cell migration and tube formation due to their direct effects on endothelial cells [111]. MT1-MMP exhibits a fibrinolytic activity, being involved in invasion of fibrin barriers and endothelial cell migration [111].

In experiments using cultures of endothelial cells on matrigel, the addition of recombinant gelatinase $A$ is followed by an amplification of tube networks, a process inhibited both by neutralizing antibody and TIMP2, demonstrating the MMPs key role. The process has a complex regulation mechanism, as excessive levels of gelatinase $A$ are inhibitory and TIMP2 may both stimulate or inhibit the angiogenic response according to the level of protease expression.

Angiogenesis and tumor invasion are stimulated by TGF- $\beta$ (transforming growth factor- $\beta$ ) activation by surfaced-anchored MMP9 [112]. Angiostatin is released by MMP2, MMP3, MMP7, MMP9, MMP12, MMP13 and MMP20 [20]. VEGF (vascular endothelial growth factor) stimulates tumor angiogenesis, being released by MMP3, MMP7, MMP9, and MMP19 [20].

The ectodomain shedding interferes with cell surface signaling by proteolytic cleavage of the extracellular domain in the juxtamembrane region of a transmembrane molecule. This process results in release of a soluble ectodomain into the pericellular space and subsequent cell-tissue interaction. The ectodomain shedding mechanism is involved in angiogenesis and tumor proliferation, as a result of MMP3 and MMP7 action on HB-EGF, in tumor invasion, by E-cadherin shaded by MMP3 and MMP7, and in tumor apoptosis by MMP7 action result on TNF- $\alpha$ (tumor necrosis factor- $\alpha$ ) [20].

MMP7 induces angiogenesis in vivo, by enhancing the endothelial cell proliferation and up-regulates endothelial expression of MMP1 and MMP2 [113]. 
The endothelial cells express MMP2, MMP9, and MT1-MMP membrane vesicles are located near pseudopodia. The stimulation of angiogenesis by bFGF or VEGF results in shedding of vesicles. Supplementary, MMP9 stimulation of bFGF enhances in vitro endothelial cell growth [114].

The endothelial cells of tumors express MMP2, MMP7, and MMP9 [115]. Moreover, MMP7 stimulates vascular proliferation [113], while matrilysin-specific antisense oligonucleotides inhibit tumoral angiogenesis.

MMPs disrupt cell-to-cell adhesion by cleaving the ectodomain of VE-cadherin [111]. MMP3, MMP7, MMP9, and MMP19 have the ability to cleave matrix-bound isoforms of VEGF, releasing it as soluble fragments which are less effective in angiogenesis than matrixbound VEGF despite their common cell surface receptor (VEGFR2) [116].

The induction of MMP9 expression in tumor macrophages and endothelial cells creates new hypothesis related to the correlation between MMPs and angiogenesis. MMPs also exhibit an inhibitory action on angiogenesis. MMP2, MMP7, MMP9 [114], and MMP12 [117] cleave plasminogen into angiostatin which promotes endothelial apoptosis and inhibits endothelial cell proliferation.

Another endogenous inhibitor of angiogenesis, endostatin is generated by MMP3, MMP7, MMP9, MMP13, and MMP20 cleavage of collagen type XVIII [118, 119]. MMPs are also capable to cleave the precursor of endostatin. Supplementary, MMP7 generates neostatin-7, the C-terminal $28-\mathrm{kDa}$ endostatin-spanning proteolytic fragment, by proteolysis of collagen XVIII [120]. Tumstatin may be generated by MMP9 proteolysis of type IV collagen, resulting in angiogenesis and tumor growth inhibition [121].

MMPs influences vascular stability and permeability, mainly by MMP14 which mediates the vascular response following tissue injuries and modulates tumor progression, by TGF- $\beta$ activation [122]. The relationship between lymphangiogenesis and tumor progression is well-known and MMPs involvement in the modulation of the above process has been experimentally demonstrated [123]. MMP1, MMP2 enhanced expression [124], along with that of MMP3 [125] are correlated to lymphatic invasion and lymph nodes metastases. MMP2, -9 , and -14 inhibition reduces angiogenesis and lymphangiogenesis, and lymph nodes metastases [126].

\section{Apoptosis and MMPs in tumoral tissues}

MMPs are involved in apoptosis regulation. By MMP7 ability to generate SFasL (soluble FasL) and subsequent Fas activation, apoptosis is stimulated [127]. This process is prevented by protein anomalies of malignant cells which result in disruptions in the signal transduction cascade of apoptosis [127]. FasL also exhibit a protective function for malignant cells from chemotherapeutic drug toxicity [128]. MMP7 expression is considered as a predictive marker for chemoresistance in patients with lung cancer [129].

MMP11 has an inhibitory action on tumor cell apoptosis but, paradoxically, an unknown mechanism of metastasis prevention has been demonstrated in experiments in transgenic mice [130].

\section{MMPs in colorectal hepatic metastases}

Metastatic and non-metastatic colorectal cancers variably express MMPs along with their specific inhibitors, such as MMP1, MMP2, MMP3, MMP7, MMP9, MMP10, MMP11, and MMP13 [54]. Thus, MMP / TIMP expression has potential value as a prognosis marker, some of them being directed toward hepatic metastases of colorectal cancers [131].

The epithelial and stromal colorectal cancer cells are responsible for production of molecules involved in matrix degradation and thus in local invasion and metastatic process [48]. MMPs produced by colorectal tumor stromal cells show contradictory expression $[63,132]$. A reason of this variability is the promoter or inhibitory action of the microenvironment.

The balances between MMP2 / TIMP2 and MMP9 / TIMP1 have been extensively studied in primary and secondary colorectal cancers 
beginning with the 90's $[64,93,133-136]$. MMP9 seems to be more involved than MMP2 [54], showing a general low MMP / strong TIMP expression in metastatic carcinomas. MMP9 positive stromal cells at the invasion front in primary carcinomas may suggest a potential direct or immune inhibitory function in hematogenous metastatic process [63].

The tumoral areas rich in MMP9 positive cells elicit an inflammatory reaction resulting in tumoral necrosis [63]. Another view is that MMP9 positive cells from the tumoral front are stimulating the inflammation, desmoplasia, and neovascularization, resulting in tumoral dissemination [132]. A similar role is attributed to stromal macrophages MMP9 positive from the periphery of hepatic metastatic nodules [48] although its expression seems to be weaker than in the primary site [132].

Starting with the 90's, strong serum and tissular MMPs and TIMPs expression result in a shorter disease-free interval and survival $[93,134,135]$. Moreover, MMP9 expression is considered as an early event in adenomacarcinoma progression [133]. Another opinion was that of a marker of intratumoral and peritumoral inflammation more likely than direct involvement in tumoral progression [137].

MMPs and TIMPs expression have been associated to useful markers of hepatic metastases [48, 138, 139], MMP2 being associated with as much as $99 \%$ predictive value for hepatic metastatic process [139]. Thus, MMPs and TIMPs seem to be associated to the development of an aggressive phenotype, with poor prognosis and short survival [136]. Post-ablative metastatic hepatic tissue exhibits an increases expression of both MMP2 and MMP9 in the transition area [65].

Histologic growth pattern of secondary hepatic tumors is determined by the response ability of metastatic cells to the hepatic microenvironment characteristics; thus, there are three growing patterns: desmoplastic, pushing, and replacement. Plasmatic level for TIMP1 is a prognosis marker for colorectal cancer, being significantly higher in patients with metastatic disease [140].
Our experience in prognosis value of MMP9/TIMP1 (Figure 1) justifies our conclusions that our study supports MMP9 and TIMP1 potential to influence the tumor progression in liver metastases. However, the confirmation of MMP9 and TIMP1 value as prognostic factors, based only on immunohistochemical expression evaluation, requires a threshold validation [141].

\section{MMPs and TIMPs in HCC}

MMPs are involved in variable normal processes, such as growth and remodelation, or pathological, such as inflammation and tumor cells migration, invasion, and metastasation. Consequently, MMPs are major components of tumor microenvironment and strong modulators of key events in liver carcinogenesis [25].

MMPs are involved in liver cirrhosis development, a well-known precursor of HCC. In experimental models, MMP9 mutation result in inhibition of fibrogenesis, with marked collagen accumulation in portal and periportal spaces and also of the stellate liver cells transdifferentiation in myofibroblast-type phenotype. Moreover, an increased activated stellate liver cell apoptosis may result by viral vector induced mutations (MMP9-H401A and MMP9E402Q) [142].

MMP9 overexpression is associated to the activation of PI3K/PTEN/AKT pathways in HCC $[143,144]$. Fas ligand is cleaved by MMP7 and becomes unable to initiate apoptosis [128]. MMP2 and MMP9 are able to modulate VEGF biodisponibility and to promote angiogenesis in HCC $[145,146]$.

MMPs also participate in the regulation of inflammatory response by cytokines and chemokines, which are also involved in cancer progression [147-149]. MMP9 is strongly expressed in HCC, showing an expression correlated to the capsular invasion [150]. By the means of osteopontin precursor cleavage and its transformation in an active form, MMP9 acts as a promoter of invasion and metastasation [151].

MMPs are liberated in their inactive forms and become activated by their catalytic site interaction [25]. By several mechanisms, such 
as coiling in position 1, interaction with X HBV protein, plasmin, furin, focal adhesion molecule (FAK), claudin-1, or other active MMPs results in their activation, thus promoting the process of liver fibrosis and HCC progression [152-155].

The use of statins as chemopreventive agents against HCC seems to be mediated by MMP2 and MMP9 inhibition and MMP14 and TIMP2 reduced expression [156].

Active MMPs are inhibited by a negative feedback loop, as a protective mechanism against excessive deterioration and tissue inflammation. MMPs activity is also regulated in genetic and transcriptional levels. TIMPs have complex roles in regulation of proliferation, apoptosis, MMPs activation, and
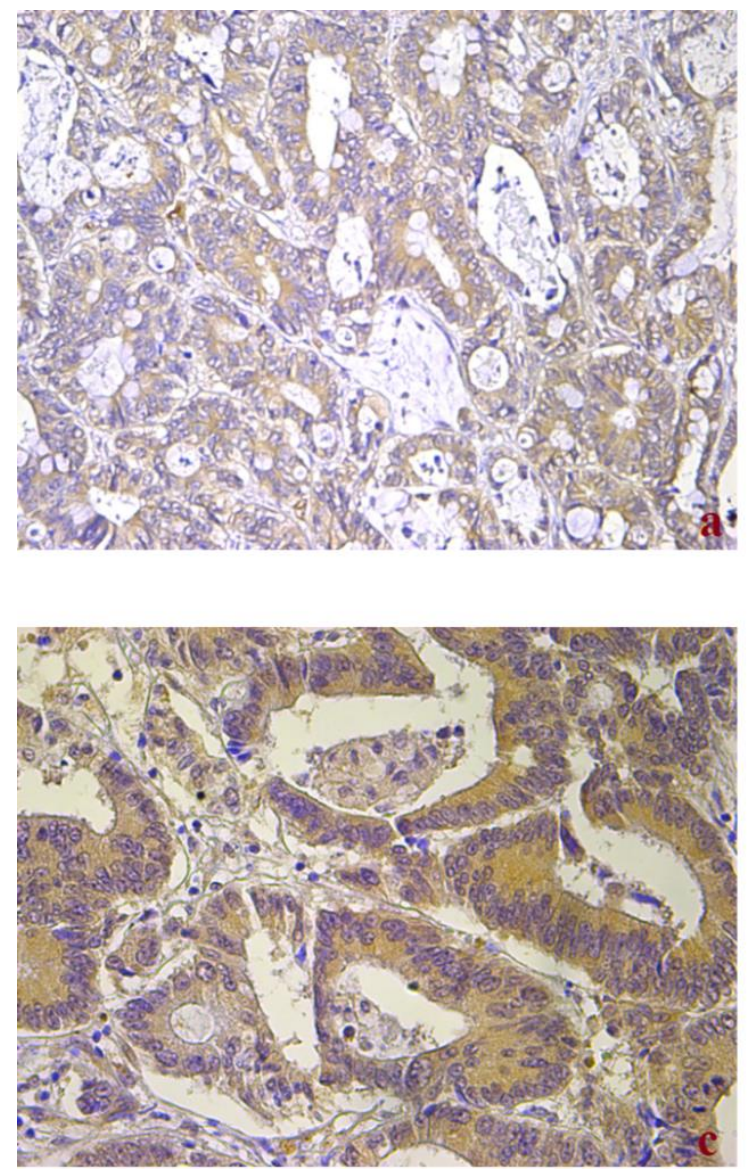

angiogenesis. TIMPs also prevent excessive ECM degradation. TIMP3 exerts an inhibitory effect on MMPs and has a limitative action in liver tumoral cells progression, invasion, and metastasation [49, 157]. TIMP1 overexpression inhibits the proliferative and invasive capacity of liver tumor cells lines [158, 159]. TIMP2 has a dual capacity to activate and inhibit MMPs. Reduced TIMP2 concentration activate MMP2 and MT1-MMP binding, as a critical step in MMP2 activation, while high TIMP2 concentrations inhibit MMP2 activation [106, 160]. MMP2 and MMP9 hyperactivation is associated to tumor invasion, metastasation, and an unfavorable prognosis in HCC evolution, as an expression of unbalanced MMPs and TIMPs levels [144].
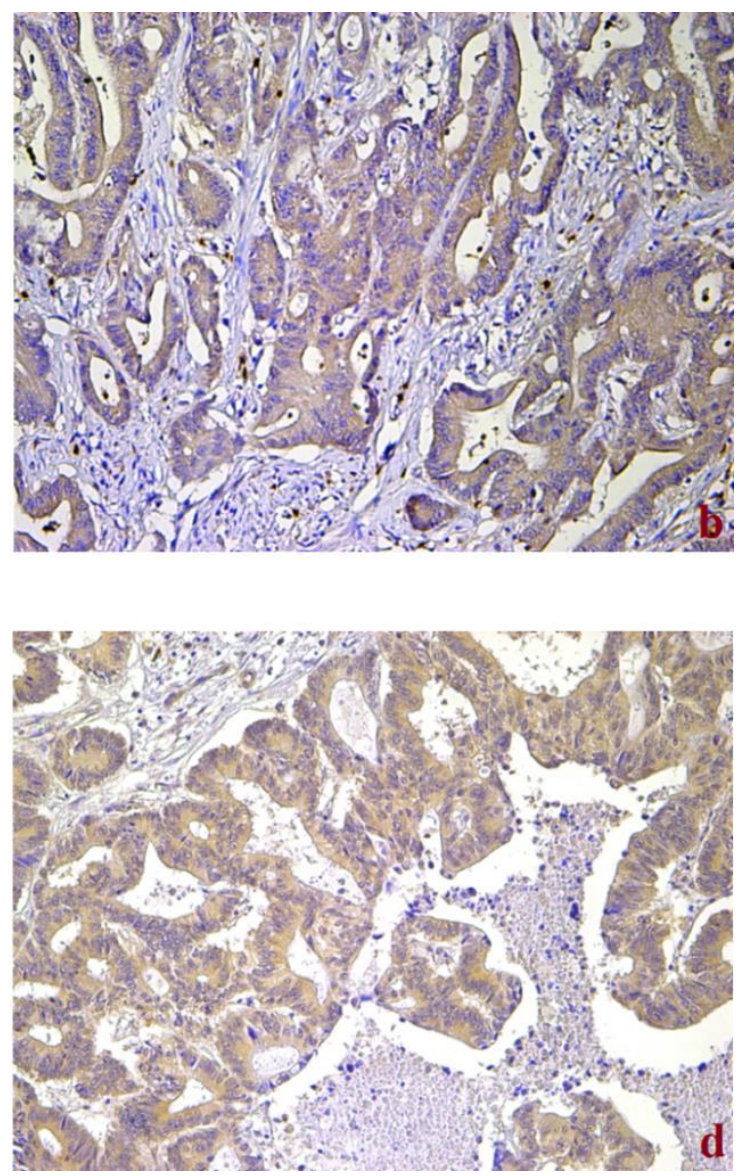

Fig. 1. MMP9 and TIMP1 expressions in liver metastases: (a) MMP9 - moderate staining intensity, $80 \%$ positive tumor cells, IHC - anti MMP9, X200; (b) TIMP1 - moderate staining intensity, 90\% positive tumor cells, IHC anti TIMP1, X200; (c) MMP9 - strong staining intensity, 100\% positive tumor cells, IHC - anti MMP9, X400;

(d)TIMP1 - strong staining intensity, 100\% positive tumor cells, IHC - anti TIMP1, X200. 


\section{Conclusions and future perspective}

MMP9 overexpression is a poor prognosis factor in hepatic metastases of colorectal cancer [63,132, 161]. Supplementary, MMP9 overexpression in HCC is associated with a poor prognosis [162] and similarly for MMP2 [163] and MMP12 [164], in experimental tumor development [165]. However, a recent study demonstrated a statistically significant longer overall survival in patients with increased serological MMP9 / TIMP1 ratio in comparison to that of patients with reduced MMP9 / TIMP1 ratio [166].

Literature review regarding MMPs and TIMPs study in primary and secondary hepatic tumors allows us to affirm that defining of a precise profile of their activities is extremely difficult $[48,131,132,161,166-171]$. The

\section{References}

1. Mbeunkui F, Johann DJ. Cancer and the tumor microenvironment: a review of an essential relationship. Cancer Chemother Pharmacol 2009; 63:571-582.

2. Hanahan D, Coussens LM. Accessories to the crime: functions of cells recruited to the tumor microenvironment. Cancer Cell 2012; 21:309322.

3. Witz IP, Levy-Nissenbaum $O$. The tumor microenvironment in the post-PAGET era. Cancer Lett 2006; 242:1-10.

4. Leonardi GC, Candido S, Cervello M, et al. The tumor microenvironment in hepatocellular carcinoma. Int J Oncol 2012; 40:1733-1747.

5. Hernandez-Gea V, Toffanin S, Friedman SL, Llovet JM. Role of the microenvironment in the pathogenesis and treatment of hepatocellular carcinoma. Gastroenterology 2013; 144:512527.

6. Yang JD, Nakamura I, Roberts LR. The tumor microenvironment in hepatocellular carcinoma: current status and therapeutic targets. Semin Cancer Biol 2011; 21(1):35-43.

7. Roskams T, Kojiro M. Pathology of early hepatocellular carcinoma: conventional and molecular diagnosis. Semin Liver Dis 2010; 30:17-25.

8. El-Serag HB. Epidemiology of hepatocellular carcinoma in USA. Hepatol Res 2007; 37:8894. expression variability of both MMPs and TIMPs is associated to promoter or inhibitor action of stromal cells and / or tumor cells, as liver microenvironment has a modulatory action for MMPs and TIMPs.

MMPs capacity to intervene in many biological processes is attributed to their ability of ECM proteolysis, as a possible initiator of unrevealed functions. The understanding of biochemical and structural aspects of MMPs, and the capacity to form molecular complexes with TIMPs open the perspectives of design of potent specific inhibitors for MMPs and, thus, the development of new therapies.

The elucidation of the complex interactions between molecules involved in proliferation and apoptosis, by future research, creates new perspectives in the early diagnosis and treatment of liver neoplasia.

9. Jemal A, Siegel R, Ward E, et al. Cancer statistics, 2009. CA Cancer J Clin 2009; 59:225-249.

10. Dooley S, Weng $H$, Mertens PR. Hypotheses on the role of transforming growth factor- $\beta$ in the onset and progression of hepatocellular carcinoma. Dig Dis 2009; 27:93-101.

11. Hoshida $Y$, Toffanin $S$, Lachenmayer A, et al. Molecular classification and novel targets in hepatocellular carcinoma: recent advancements. Semin Liver Dis 2010; 30:3551.

12. Whittaker $S$, Marais $R$, Zhu AX. The role of signaling pathways in the development and treatment of hepatocellular carcinoma. Oncogene 2010; 29:4989-5005.

13. Lee JS, Thorgeirsson SS. Comparative and integrative functional genomics of HCC. Oncogene 2006; 25:3801-3809.

14. Mohla S, Witz IP. The 5th International Conference on Tumor Microenvironment: Progression, Therapy and Prevention Versailles, France, October 20-24, 2009: conference summary. Cancer Microenviron 2010; 3:1-5.

15. Sternlicht MD, Werb Z. How matrix metalloproteinases regulate cell behavior. Annu Rev Cell Dev Biol 2001; 17:463-516.

16. Bruner-Tran K, Eisenberg E, Yeaman GR, et al. Steroid and Cytokine Regulation of Matrix Metalloproteinase Expression in Endometriosis 
and the Establishment of Experimental Endometriosis in Nude Mice. J Clin Endocrinol Metab 2002; 87(10):4782-4791.

17. Chung HW, Lee JY, Moon HS, et al. Matrix metalloproteinase-2, membranous type 1 matrix metalloproteinase, and tissue inhibitor of metalloproteinase-2 expression in ectopic and eutopic endometrium. Fertil Steril 2002; 78:787-795.

18. Visse $R$, Nagase $H$. Matrix metalloproteinases and tissue inhibitors of metalloproteinases: structure, function and biochemistry. Circ Res 2003; 92:827-839.

19. Gross J, Lapiere C. Collagenolytic activity in amphibian tissues: a tissue culture assay. Proc Natl Acad Sci USA 1962; 48(6):1014-1022.

20. Ii $M$, Yamamoto $H$, Adachi $Y$, et al. Role of MMP-7 (Matrilysin) in human cancer invasion, apoptosis, growth, and angiogenesis. Exp Biol Med 2005; 231:20-27.

21. Brummer $O$, Bohmer G, Hollwitz B, et al. MMP1 and MMP-2 in the cervix uteri in different steps of malignant transformation-an immunohistochemical study. Gynecol Oncol 2002; 84(2):222-227.

22. Curry TE, Osteen KG. The matrix metalloproteinase system: changes, regulation, and impact throughout the ovarian and uterine reproductive cycle. Endocrine Reviews 2003; 24:428-465.

23. Folgueras AR, Pendas AM, Sanchez LM, Lopez-Otin C. Matrix metalloproteinases in cancer: from new functions to improved inhibition strategies. Int J Dev Biol 2004; 48:411-424.

24. Hashizume K. Analysis of utero-placentalspecific molecules and their functions during implantation and placentation in the bovine. $J$ Reprod Dev 2007; 53(1):1-11.

25. Kessenbrock K, Plaks V, Werb Z. Matrix metalloproteinases: regulators of the tumor microenvironment. Cell 2010; 141:52-67.

26. Osteen $\mathrm{KG}$, Igarashi $\mathrm{TM}$, Bruner-Tran $\mathrm{KL}$. Progesterone action in the human endometrium: induction of a unique tissue environment which limits matrix metalloproteinase (MMP) expression. Front Biosci 2003; 8:78-86.

27. Overall CM. Molecular determinants of metalloproteinase substrate specificity: matrix metalloproteinase substrate binding domains, modules, and exosites. Mol Biotechnol 2002; 22:51-86.

28. Yadav SS, Mandal RK, Singh MK, Usman K, Khattri S. Genetic variants of matrix metalloproteinase (MMP2) gene influence metabolic syndrome susceptibility. Genet Test Mol Biomarkers 2014; 18(2):88-92.

29. Edwards DR, Handsley MM, Pennington CJ. The ADAM metalloproteinases. Mol Aspects Med 2008; 29:258-289.

30. Brew K, Dinakarpandian D, Nagase H. Tissue inhibitors of metalloproteinases: evolution, structure and function. Biochim Biophys Acta 2000; 1477(1-2):267-283.

31. Murphy G. Tissue inhibitors of metalloproteinases. Genome Biol 2011; 12(11):233-241.

32. Baker A, Edwards D, Murphy G. Metalloproteinase inhibitors: biological actions and therapeutic opportunities. J Cell Sci 2002; 115:3719-3727.

33. Edwards DR, Beaudry PP, Laing TD, et al. The roles of tissue inhibitors of metalloproteinases in tissue remodelling and cell growth. Int $J$ Obes Relat Metab Disord 1996; 20(3):9-15.

34. Arpino V, Brock M, Gill SE. The role of TIMPs in regulation of extracellular matrix proteolysis. In: Matrix Biology, Parks wc, Apte S. (eds.), Philadelphia: Elsevier B.V., 2015; 44-46:247254.

35. McLennan SV, Wang XY, Moreno V, Yue DK, Twigg SM. Connective tissue growth factor mediates high glucose effects on matrix degradation through tissue inhibitor of matrix metalloproteinase type 1: implications for diabetic nephropathy. Endocrinology 2004; 145:5646-5655.

36. Lieu S, Hansen E, Dedini R, et al. Impaired remodeling phase of fracture repair in the absence of matrix metalloproteinase-2. Dis Model Mech 2011; 4:203-211.

37. Aoki M, Miyake K, Ogawa R, et al. siRNA knockdown of tissue inhibitor of metalloproteinase-1 in keloid fibroblasts leads to degradation of collagen type I. J Invest Dermatol 2014; 134:818-826.

38. Yang J, Zheng J, Wu L, et al. NDRG2 ameliorates hepatic fibrosis by inhibiting the TGF- $\beta 1 /$ Smad pathway and altering the MMP2/TIMP2 ratio in rats. PLoS One 2011; 6:e27710. http://dx.doi.org/10.1371/journal. pone.0027710.

39. Sokolović A, Rodriguez-Ortigosa CM, Ten Bloemendaal L, Oude Elferink RPJ, Prieto J, Bosma PJ. Insulin-like growth factor 1 enhances bile-duct proliferation and fibrosis in Abcb4(-/-) mice. Biochim Biophys Acta 2013; 1832:697-704.

40. Pushpakumar S, Kundu S, Pryor T, et al. Angiotensin-II induced hypertension and renovascular remodelling in tissue inhibitor of 
metalloproteinase 2 knockout mice. $J$ Hypertens 2013; 31:2270-2281.

41. Ratajczak-Wielgomas $\mathrm{K}$, Gosk J, Rabczyński J, et al. Expression of MMP- 2, TIMP-2, TGF- $\beta 1$, and decorin in Dupuytren's contracture. Connect Tissue Res 2012; 53:469-477.

42. Georgescu SP, Aronovitz MJ, lovanna JL, Patten RD, Kyriakis JM, Goruppi S. Decreased metalloprotease 9 induction, cardiac fibrosis, and higher autophagy after pressure overload in mice lacking the transcriptional regulator $\mathrm{p} 8$. Am J Physiol Cell Physiol 2011; 301:1046-56.

43. Black RA. TIMP3 checks inflammation. Nat Genet 2004; 36:934-935.

44. Watanabe-Takano $\mathrm{H}$, Takano $\mathrm{K}$, et al. DA-Rafdependent inhibition of the Ras-ERK signaling pathway in type 2 alveolar epithelial cells controls alveolar formation. Proc Natl Acad Sci U S A 2014; 111:E2291-300.

45. Shynlova O, Bortolini MAT, Alarab M. Genes responsible for vaginal extracellular matrix metabolism are modulated by women's reproductive cycle and menopause. Int Braz $J$ Urol 2013; 39:257-267.

46. Fountoulakis N, Labiris G, Aristeidou A, et al. Tissue inhibitor of metalloproteinase 4 in aqueous humor of patients with primary open angle glaucoma, pseudoexfoliation syndrome and pseudoexfoliative glaucoma and its role in proteolysis imbalance. BMC Ophthalmol 2013;13:69. http://dx.doi.org/10.1186/14712415-13-69.

47. Kyle DJT, Harvey AG, Shih B, Tan KT, Chaudhry $\mathrm{IH}$, Bayat $A$. Identification of molecular phenotypic descriptors of breast capsular contracture formation using informatics analysis of the whole genome transcriptome. Wound Repair Regen 2013; 21:762-769.

48. Zeng ZS, Shu WP, Cohen AM, Guillem JG. Matrix metalloproteinase-7 expression in colorectal cancer liver metastases: evidence for involvement of MMP-7 activation in human cancer metastases. Clin Cancer Res 2002; 8(1):144-148.

49. $\mathrm{Qi} \mathrm{JH}$, Ebrahem $\mathrm{Q}$, Moore $\mathrm{N}$, et al. A novel function for tissue inhibitor of metalloproteinases-3 (TIMP3): inhibition of angiogenesis by blockage of VEGF binding to VEGF receptor-2. Nat Med 2003; 9:407-415.

50. Collette $\mathrm{T}$, Bellehumeur $\mathrm{C}$, Kats $\mathrm{R}$, et al. Evidence for an increased release of proteolytic activity by the ectopic endometrial tissue in women with endometriosis and for involvement of matrix metalloproteinase-9. Hum Reprod 2004; 19(6):1257-1264.
51. Butler GS, Overall CM. Updated biological roles for matrix metalloproteinases and new "intracellular" substrates revealed by degradomics. Biochemistry 2009; 48(46):10830-10845.

52. Klein $T$, Bischoff $R$. Physiology and pathophysiology of matrix metalloproteases. Amino Acids 2011; 41(2):271-290.

53. Poswar FO, Fraga CA, Farias LC, et al. Immunohistochemical analysis of TIMP-3 and MMP-9 in actinic keratosis, squamous cell carcinoma of the skin, and basal cell carcinoma. Pathol Res Pract 2013; 209(11):705-709.

54. Zucker S, Vacirca J. Role of matrix metalloproteinases (MMPs) in colorectal cancer. Cancer Metastasis Rev 2004; 23(12):101-117.

55. Basset $P$, Bellocq JP, Wolf $C$, et al. A novel metalloproteinase gene specifically expressed in stromal cells of breast carcinomas. Nature 1990; 348(6303):699-704.

56. Hashimoto K, Kihira $\mathrm{Y}$, Matuo $\mathrm{Y}$, Usui $\mathrm{T}$. Expression of matrix metalloproteinase-7 and tissue inhibitor of metalloproteinase- 1 in human prostate. J Urol 1998; 160(5):1872-1876.

57. Oikonomidi S, Kostikas K, Tsilioni I, Tanou K, Gourgoulianis KI, Kiropoulos TS. Matrix metalloproteinases in respiratory diseases: from pathogenesis to potential clinical implications. Curr Med Chem 2009; 16:12141228.

58. Groblewska M, Siewko M, Mroczko B, Szmitkowski M. The role of matrix metalloproteinases (MMPs) and their inhibitors (TIMPs) in the development of esophageal cancer. Folia Histochem Cytobiol 2012; 50:1219.

59. Zhang M, Zhu GY, Gao HY, Zhao SP, Xue Y. Expression of tissue levels of matrix metalloproteinases and tissue inhibitorsof metalloproteinases in gastric adenocarcinoma. J Surg Oncol 2011; 103(3):243-247.

60. Zhang QW, Liu L, Chen R, et al. Matrix metalloproteinase- 9 as a prognostic factor in gastric cancer: a meta-analysis. Asian Pac $J$ Cancer Prev 2012; 13(6):2903-2908.

61. Ueno H, Yamashita K, Azumano I, Inoue M, Okada Y. Enhanced production and activation of matrix metaslloproteinase-7 (matrilysin) in human endometrial carcinomas. Int $J$ Cancer 1999; 84:470-477.

62. Sakata K, Shigemasa K, Nagai N, Ohama K. Expression of matrix metalloproteinases (MMP2, MMP-9, MT1-MMP) and their inhibitors 
(TIMP-1, TIMP-2) in common epithelial tumors of the ovary. Int J Oncol 2000; 17(4):673-681.

63. Saito K, Takeha S, Shiba K, et al. Clinicopathologic significance of urokinase receptorand MMP-9-positive stromal cells in human colorectal cancer: functional multiplicity of matrix degradation on hematogenous metastasis. Int J Cancer 2000; 86(1):24-29.

64. Poulsom R, Pignatelli $M$, Stetler-Stevenson WG, et al. Stromal expression of 72 Kda type IV collagenase (MMP-2) and TIMP-2 mRNAs in colorectal neoplasia. Am J Pathol 1992; 141(2):389-396.

65. Frich L, Bjørnland K, Pettersen S, Clausen OP, Gladhaug IP. Increased activity of matrix metalloproteinase 2 and 9 after hepatic radiofrequency ablation. J Surg Res 2006; 135:297-304.

66. Johansson $\mathrm{N}$, Ala-Aho $\mathrm{R}$, Uitto $\mathrm{V}$, et al. Expression of collagenase-3 (MMP-13) and collagenase-1 (MMP-1) by transformed keratinocytes is dependent on the activity of p38 mitogen-activated protein kinase. J Cell Sci 2000; 113(2):227-235.

67. Liu D, Guo H, Li Y, Xu X, Yang K, Bai Y. Association between polymorphisms in the promoter regions of matrix metalloproteinases (MMPs) and risk of cancer metastasis: a metaanalysis. PLoS ONE 2012; 7:e31251.

68. O'byrne EM, Parker DT, Roberts ED, et al. Oral administration of a matrix metalloproteinase inhibitor, CGS 27023A, protects the cartilage proteoglycan matrix in a partial meniscectomy model of osteoarthritis in rabbits. Inflam Res 1995; 44:117-118.

69. Cawston TE. Metalloproteinase inhibitors and the prevention of tissue breakdown. Pharm Ther 1996; 70:163-182.

70. Saarialho-Kere UK, Vaalamo M, KarjalainenLindsberg ML, Airola K, Parks WC, Puolakkainen P. Enhanced expression of matrilysin, collagenase, and stromelysin-1 in gastrointestinal ulcers. Am J Pathol 1996; 148:519-526.

71. Rosenberg GA. Matrix metalloproteinases in brain injury. J Neurotrauma 1995; 12:833-842.

72. Chandler S, Coates R, Gearing A, Lury J, Wells G, Bone E. Matrix metalloproteinases degrade myelin basic protein. Neurosci Lett 1995; 201:223-226.

73. Woessner JF. The Matrix Metalloproteinase Family. In: Parks WC, Mecham RP. (eds.), Matrix metalloproteinases. San Diego, California: Academic Press; 1998:1-14.

74. Thompson RW, Parks WC. Role of matrix metalloproteinases in abdominalaortic aneurysms. Ann N Y Acad Sci 1996; 800:157174.

75. Strauss $B H$, Robinson R, Batchelor WB. In vivo collagen turnover following experimental balloon angioplasty injury and the role of matrix. Circulation Research 1996; 79:541-550.

76. Nelson AR, Fingleton B, Rothenberg ML, Matrisian LM. Matrix metalloproteinases: biologic activity and clinical implications. J Clin Oncol 2000; 18(5):1135-1149.

77. Noe V, Fingleton B, Jacobs K, et al. Release of an invasion promoter E-cadherin fragment by matrilysin and stromelysin-1. J Cell Sci 2001; 114:111-118.

78. Lynch CC, Hikosaka A, Acuff HB. MMP-7 promotes prostate cancer-induced osteolysis via the solubilization of RANKL. Cancer Cell 2005; 7(5):485-496.

79. Shiomi T, Okada Y. MT1-MMP and MMP-7 in invasion and metastasis of human cancers. Cancer and Metastasis Rev 2003; 22:145-152.

80. Mannello F, Gazzanelli G. Tissue inhibitors of metalloproteinases and programmed cell death: conundrums, controversies and potential implications. Apoptosis 2001; 6:479-482.

81. Gersch I, Catchpole HR. The organization of ground substance and basement membrane and its significance in tissue injury, disease and growth. Am J Anat 1949; 85:457-507.

82. Deryugina El, Quigley JP. Matrix metalloproteinases and tumor metastasis. Cancer Metastasis Rev 2006; 25(1):9-34.

83. Heppner KJ, Matrisian LM, Jensen RA, Rodgers WH. Expression of most matrix metalloproteinase family members in breast cancer respresents a tumor-induced host response. Am J Pathol 1996; 149:273-282.

84. Okada $N$, Ishida $H$, Murata N, Hashimoto D, Seyama Y, Kubota S. Matrix metalloproteinase2 and -9 in bile as a marker of liver metastasis in colorectal cancer. Biochem Biophys Res Commun 2001; 288(1):212-216.

85. Ray JM, Stetler-Stevenson WG. Gelatinase A activity directly modulates melanoma cell adhesion and spreading. EMBO J 1995; 14:908-917.

86. Giannelli G, Falk-Marzillier J, Schiraldi $O$, Stetler-Stevenson WG, Quaranta V. Induction of cell migration by matrix metalloproteinase-2 cleavage of laminin-5. Science 1997; 277:225228.

87. Laurie GW, Leblond CP, Martin GR. Localization of type IV collagen, laminin, heparan sulfate proteoglycan, and fibronectin to the basal lamina of basement membranes. $J$ Cell Biol 1982; 95:340-344. 
88. Burgeson, RE, Chiquet M, Deutzmann R, et al. A new nomenclature for the laminins. Matrix Biol 1994; 14:209-211.

89. Stefansson S, Lawrence DA. The serpin PAI-1 inhibits cell migration by blocking integrin alpha $\mathrm{V}$ beta 3 binding to vitronectin. Nature 1996; 383:441-443.

90. Nagase H, Visse R, Murphy G. Structure and function of matrix metalloproteinases and TIMPs. Cardiovascular Research 2006; 69:562-573.

91. Gress TM, Muller-Pillasch F, Lerch MM, Friess $\mathrm{H}$, Buchler M, Adler G. Expression and in-situ localization of genes coding for extracellular matrix proteins and extracellular matrix degrading proteases in pancreatic cancer. Int $J$ Cancer 1995; 2:407-413.

92. Pei D. Leukolysin/MMP25/MT6-MMP: a novel matrix metalloproteinase specifically expressed in the leukocyte lineage. Cell Res 1999; 9(4):291-303.

93. Zeng ZS, Huang Y, Cohen AM, Guillem JG. Prediction of colorectalcancer relapse and survival via tissue RNA levels of matrix metalloproteinase-9. J Clin Oncol 1996; 14:3133-3140.

94. Zeng Z, Cohen AM, Zhang Z, StetlerStevenson WG, Guillem JG. Elevated tissue inhibitor of metalloproteinase 1 RNA in colorectal cancer stroma correlates with lymph node and distant metastases. Clin Cancer Res 1995; 1:899-906.

95. Sier CFM, Kubben FJGM, Ganesh S, et al. Tissue levels of matrix metalloproteinases MMP-2 and MMP-9 are related to the overall survival of patients with gastric carcinoma. $\mathrm{Br} \mathrm{J}$ Cancer 1996; 74:413-417.

96. Chenard MP, O'siorain L, Shering S, et al. High levels of stromelysin-3 correlate with poor prognosis in patients with breast carcinoma. Int J Cancer 1996; 69:448-451.

97. Fong KM, Kida Y, Zimmerman PV, Smith PJ. TIMP1 and adverse prognosis in non-small cell lung cancer. Clin Cancer Res 1996; 2:13691372.

98. Grignon DJ, Sakr W, Toth M. High levels of tissue inhibitor ofmetalloproteinase-2 (TIMP-2) expression are associated with poor outcome in invasive bladder cancer. Cancer Res 1996; 56:1654-1659.

99. Murray GI, Duncan ME, O'neil P, Melvin WT, Fothergill JE. Matrix metalloproteinase-1 is associated with poor prognosis in colorectal cancer. Nature Med 1996; 2:461-462.

100.Gallegos NC, Smales C, Savage FG, Hembry $\mathrm{RM}$, Boulos PB. The distribution of matrix metalloproteinases and tissue inhibitor of metalloproteinases in colorectal cancer. Surgical Oncol 1995; 4:21-29.

101. Brooks PC, Stromblad S, Sanders LC. Localization of matrix metalloproteinase MMP-2 to the surface of invasive cells by interaction with integrin alpha v beta 3. Cell 1996; 85:683693.

102. Macdougall JR, Matrisian LM. Contributions of tumor and stromal matrix metalloproteinases to tumor progression, invasion and metastasis. Cancer Metast Rev 1995; 14:351-362.

103. Houghton AM, Grisolano JL, Baumann ML. Macrophage elastase (matrix metalloproteinase-12) suppresses growth of lung metastases. Cancer Res 2006; 66(12):6149-6155.

104.Shapiro SD, Kobayashi DK, Ley TJ. Cloning and characterization of a unique elastolytic metalloproteinase produced by human alveolar macrophages. J Biol Chem 1993; 268:2382423829.

105. Heppner KJ, Matrisian LM, Jensen RA, Rodgers $\mathrm{WH}$. Expression of most matrix metalloproteinase family members in breast cancer respresents a tumor-induced host response. Am J Pathol 1996; 149:273-282.

106.Strongin AY, Collier I, Bannikov G, Marmer BL, Grant GA, Goldberg GI. Mechanism of cell surface activation of $72-\mathrm{kDa}$ type IV collagenase. Isolation of the activated form of the membrane metalloprotease. $J$ Biol Chem 1995; 270:5331-5338.

107.Gohji K, Fujimoto N, Fujii A, Komiyama T, Okawa J, Nakajima M. Prognostic significance of circulating matrix metalloproteinase-2 to tissue inhibitor of metalloproteinase-2 ratio in recurrence ofurothelial cancer after complete resection. Cancer Res 1996; 56:3196-3198.

108. Onisto M, Riccio MP, Scannapieco $P$, et al. Gelatinase A/TIMP-2 imbalance in lymphnodepositive breast carcinomas, as measured by RT-PCR. Int J Cancer 1995; 3:621-626.

109. Egeblad M, Werb Z. New functions for the matrix metalloproteinases in cancer progression. Nat Rev Canc 2002; 2(3):161-174.

110. Hojilla CV, Mohammed FF, Khokha R. Matrix metalloproteinases and their tissue inhibitors direct cell fate during cancer development. $\mathrm{Br} \mathrm{J}$ Canc 2003; 10:1817-1821.

111. Rundhaug JE. Matrix metalloproteinases and angiogenesis. J Cell Mol Med 2005; 9(2):267285.

112.Yu Q, Stamenkovic I. Cell surface-localized Matrix Metalloproteinase-9 proteolytically activates TGF- $\beta$ and promotes tumor invasion 
and angiogenesis. Genes \& Development 2000; 14:163-176.

113. Huo $\mathrm{N}$, Ichikawa $\mathrm{Y}$, Kamiyama $\mathrm{M}$, et al. MMP-7 (matrilysin) accelerated growth of human umbilical vein endothelial cells. Cancer Lett 2002; 177(1):95-100.

114.Pozzi A, Levine WF, Gradner HA. Low plasma levels of MMP9 permit increased tumor angiogenesis. Oncogene 2002; 21:272-281.

115. Thorns V, Walter GF, Thorns C. Expression of MMP-2, MMP-7, MMP-9, MMP-10 and MMP11 in human astrocytic and oligodendroglial gliomas. Anticancer Res 2003; 23(5A):39373944.

116. Lee MH, Murphy G. Matrix metalloproteinases at a glance. J Cell Science 2004; 117:40154016.

117. Cornelius LA, Nehring LC, Harding E, et al. Matrix metalloproteinases generate angiostatin: effects on neovascularization. J Immunol 1998; 161(12):6845-6852.

118. Ferreras $M$, Felbor U, Lenhard $T$, Olsen BR, Delaissé JM. Generation and degradation of human endostatin proteins by various proteinases. FEBS Letters 2000; 486:247-251.

119. Heljasvaara R, Nyberg $P$, Luostarinen J, et al. Generation of biologically active endostatin fragments from human collagen XVIII by distinct matrix metalloproteases. Exp Cell Res 2005; 307(2):292-304.

120.Chang JH, Javier JA, Chang GY, Oliveira HB, Azar DT. Functional characterization of neostatins, the MMP-derived, enzymatic cleavage products of type XVIII collagen. FEBS Lett 2005; 579(17):3601-3606.

121. Hamano $Y$, Zeisberg $M$, Sugimoto $H$. Physiological levels of tumstatin, a fragment of collagen IV alpha3 chain, are generated by MMP-9 proteolysis and suppress angiogenesis via alphaV beta3 integrin. Cancer Cell 2003; 3:589-601.

122.Sounni NE, Dehne K, van Kempen LLCL, et al. Stromal regulation of vessel stability by MMP9 and TGF $\beta$. Dis Model Mech 2010; 3(5-6):317332

123. Bruyere $F$, Melen-Lamalle $L$, Blacher $S$, et al. Modeling lymphangiogenesis in a threedimensional culture system. Nat Methods 2008; 5:431-437.

124.Langenskiold $M$, Holmdahl L, Falk $P$, Ivarsson ML. Increased plasma MMP-2 protein expression in lymph node-positive patients with colorectal cancer. Int J Colorectal Dis 2005; 20:245-252.

125. Islekel H, Oktay G, Terzi C, Canda AE, Fuzun M, Kupelioglu A. Matrix metalloproteinase-9,-3 and tissue inhibitor of matrix metalloproteinase1 in colorectal cancer: relationship to clinicopathological variables. Cell Biochem Funct 2007; 25:433-441.

126. Nakamura ES, Koizumi K, Kobayashi M, Saiki I. Inhibition of lymphangiogenesis-related properties of murine lymphatic endothelial cells and lymph node metastasis of lung cancer by the matrix metalloproteinase inhibitor MMI270. Cancer Sci 2004; 95:25-31.

127.Vargo-Gogola T, Fingleton B, Crawford HC, Matrisian LM. Matrilysin (matrix metalloproteinase-7) selects for apoptosisresistant mammary cells in vivo. Cancer Res 2002; 62(19):5559-5563.

128. Mitsiades $\mathrm{N}$, Yu WH, Poulaki V, Tsokos $M$, Stamenkovic I. Matrix metalloproteinase-7mediated cleavage of Fas ligand protects tumor cells from chemotherapeutic drug cytotoxicity. Cancer Res 2001; 61(2):577-5781.

129. Liu H, Zhang T, Li X, et al. Predictive value of MMP-7 expression for response to chemotherapy and survival in patients with non-small cell lung cancer. Cancer Sci 2008; 99:2185-2192.

130. Andarawewa $K L$, Boulay $A$, Masson $R$, et al. Dual stromelysin-3 function during natural mouse mammary tumor virus-ras tumor progression. Cancer Res 2003; 63:5844-5849.

131.Waas ET, Wobbes T, Lomme RM, et al Matrix metalloproteinase 2 and 9 activity in patients with colorectal cancer liver metastasis. $\mathrm{Br} \mathrm{J}$ Surg 2003; 90(12):1556-1564.

132. Illemann M, Bird N, Majeed A, et al. MMP-9 is differentially expressed in primary human colorectal adenocarcinomas and their metastases. Mol Cancer Res 2006; 4(5):293302.

133.Parsons SL, Watson SA, Collins HM, et al. Gelatinase (MMP-2 and -9) expression in gastrointestinal malignancy. Br J Cancer 1998; 78(11):1495-1502.

134.Ring $P$, Johansson K, Höyhtyä M, Rubin K, Lindmark $G$. Expression of tissue inhibitor of metalloproteinases TIMP-2 in human colorectal cancer - a predictor of tumour stage. $\mathrm{Br} \mathrm{J}$ Cancer 1997; 76(6):805-811.

135.Joo YE, Seo KS, Kim J, et al. Role of tissue inhibitors of metalloproteinases (TIMPs) in colorectal carcinoma. J Korean Med Sci 1999; 14(4):417-442.

136. Lyall MS, Dundas SR, Curran S, Murray GI. Profiling markers of prognosis in colorectal cancer. Clin Cancer Res 2006; 12(4):11841191. 
137. Nielsen BS, Timshel S, Kjeldsen L, et al. 92 $\mathrm{kDa}$ type IV collagenase (MMP-9) is expressed in neutrophils and macrophages but not in malignant epithelilal cells in human colon cancer. Int J Cancer 1999; 365:57-62.

138. Howell R, Roche W, Rees M, Blaydes J, Primrose J. TIMP-1 expression in colorectal cancer liver metastases is associated with poor outcome. Proc Am Soc Clin Oncol 2002; $21: 1758$.

139.Barozzi C, Ravaioli M, D'Errico A, et al. Relevance of biological markers in colorectal carcinoma. A comparative study of a broad panel. Cancer 2002; 94:647-657.

140. Illemann M, Eefsen $\mathrm{RH}$, Bird NC, et al. Tissue inhibitor of matrix metalloproteinase-1 expression in colorectal cancer liver metastases is associated with vascular structures. Mol Carcinog 2015; 1-16. Doi:10.1002/mc.22269.

141. Giuşcă SE, Căruntu ID, Amălinei $C$, Avădănei ER. Prognostic significance of MMP-9 and TIMP-1 in liver metastases. Rom $J$ Morphol Embryol 2015, 56(2):357-364.

142. Roderfeld $M$, Weiskirchen $R$, Wagner $S$, et al. Inhibition of hepatic fibrogenesis by matrix metalloproteinase-9 mutants in mice. Faseb $J$ 2006; 20:444-454.

143.Cheng JC, Chou CH, Kuo ML, Hsieh CY. Radiation-enhanced hepatocellular carcinoma cellinvasion with MMP-9 expression through $\mathrm{PI3K} / \mathrm{Akt} / \mathrm{NF}-\mathrm{kappaB}$ signal transduction pathway. Oncogene 2006; 25:7009-7018.

144.Chen JS, Wang Q, Fu XH, et al. Involvement of $\mathrm{PISK} / \mathrm{PTEN} / \mathrm{AKT} / \mathrm{mTOR}$ pathway in invasion and metastasis in hepatocellular carcinoma: Association with MMP-9. Hepatol Res 2009; 39:177-86.

145. Littlepage LE, Sternlicht MD, Rougier N, et al. Matrix metalloproteinases contribute distinct roles in neuroendocrine prostate carcinogenesis, metastasis, and angiogenesis progression. Cancer Res 2010; 70: 2224-2234.

146.Kohga $\mathrm{K}$, Tatsumi $\mathrm{T}$, Takehara $\mathrm{T}$, et al. Expression of CD133 confers malignant potential by regulating metalloproteinases in human hepatocellular carcinoma. I Hepatol 2010; 52:872-879.

147.Parks WC, Wilson CL, Lopez-Boado YS. Matrix metalloproteinases as modulators of inflammation and innate immunity. Nat Rev Immunol 2004; 4:617-629.

148. Lin WW, Karim M. A cytokine-mediated link between innate immunity, inflammation, and cancer. J Clin Invest 2007; 117:1175-1183.
149.Manicone AM, McGuire JK. Matrix metalloproteinases as modulators of inflammation, Semin Cel Dev Biol 2008; 19:3441.

150.Arii S, Mise M, Harada T, et al. Overexpression of matrix metalloproteinase 9 gene in hepatocellular carcinoma with invasive potential. Hepatology 1996; 24:316-322.

151.Takafuji V, Forgues M, Unsworth E, Goldsmith $\mathrm{P}$, Wang $\mathrm{XW}$. An osteopontin fragment is essential for tumor cell invasion in hepatocellular carcinoma. Oncogene 2007, 26:6361-6371.

152. Yu FL, Liu HJ, Lee JW, et al. Hepatitis B virus $X$ protein promotes cell migration by inducing matrix metalloproteinase-3. J Hepatol 2005; 42:520-527.

153.Ou DP, Tao YM, Tang FQ, Yang LY. The hepatitis $B$ virus $X$ protein promotes hepatocellular carcinoma metastasis by upregulation of matrix metalloproteinases. Int $\mathrm{J}$ Cancer 2007; 120:1208-1214.

154. Woo HG, Park ES, Cheon JH, et al. Gene expression-based recurrence prediction of hepatitis B virus-related human hepatocellular carcinoma. Clin Cancer Res 2008; 14:20562064.

155.Zhao XL, Sun $T$, Che $N$, et al. Promotion of hepatocellular carcinoma metastasis through matrix metalloproteinase activation by epithelial-mesenchymal transition regulator twist1. J Cell Mol Med 2011; 15(3):691-700.

156.Taras D, Blanc JF, Rullier A, Dugot-Senant N, et al. Pravastatin reduces lung metastasis of rat hepatocellular carcinoma via a coordinated decrease of MMP expression and activity. $J$ Hepatol 2007; 46:69-76.

157.Zhang H, Wang YS, Han G, Shi Y. TIMP-3 gene transfection suppresses invasive and metastatic capacity of human hepatocarcinoma cell line HCC-7721. Hepatobiliary Pancreat Dis Int 2007; 6:487-491.

158. Kim JR, Kim CH. Association of a high activity of matrix metalloproteinase-9 to low levels of tissue inhibitors of metalloproteinase- 1 and -3 in human hepatitis B-viral hepatoma cells. Int $J$ Biochem Cell Biol 2004; 36:2293-306.

159.Xia D, Yan LN, Xie JG, et al. Overexpression of TIMP-1 mediated by recombinant adenovirus in hepatocellular carcinoma cells inhibits proliferation and invasion in vitro. Hepatobiliary Pancreat Dis Int 2006; 5:409-415.

160. Kinoshita T, Sato H, Okada A, et al. TIMP-2 promotes activation of progelatinase $A$ by membrane-type 1 matrix metalloproteinase 
immobilized on agarose beads. $J$ Biol Chem 1998; 273:16098-16103

161.Gorden DL, Fingleton B, Crawford HC, et al. Resident stromal cell-derived MMP-9 promotes the growth of colorectal metastases in the liver microenvironment. Int $J$ Cancer 2007; 121(3):495-500.

162. Nart D, Yaman B, Yilmaz F, et al. Expression of matrix metalloproteinase-9 in predicting prognosis of hepatocellular carcinoma after liver transplantation. Liver Transp 2010; 16(5):621-630.

163. Giannelli G, Fransvea E, Bergamini C, et al. Laminin-5 chains are expressed differentially in metastatic and nonmetastatic hepatocellular carcinoma. Clin Cancer Res 2003; 9:36843691.

164.Ng KT, Qi X, Kong KL, et al. Overexpression of matrix metalloproteinase-12 (MMP-12) correlates with poor prognosis of hepatocellular carcinoma. Eur J Cancer 2011; 47(15):22992305.

165. Thieringer FR, Maass $T$, Anthon B, et al. Liverspecific overexpression of matrix metalloproteinase 9 (MMP-9) in transgenic mice accelerates development of hepatocellular carcinoma. Mol Carcinog 2012; 51(6):439-448.

166.Lempinen M, Lyytinen I, Nordin A. Prognostic value of serum MMP-8, -9 and TIMP-1 in patients with hepatocellular carcinoma. Ann Med 2013; 45(7):482-487.
167. Ogawa $M$, Ikeuchi $K$, Watanabe $M$, et al. Expression of matrix metalloproteinase 7, laminin and type IV collagen-associated liver metastasis in human colorectal cancer: immunohistochemical approach, Hepatogastroenterol 2005; 52(63):875-880.

168.Sutnar A, Pesta M, Liska V, et al. Clinical relevance of the expression of MRNA of MMP7, MMP-9, TIMP-1, TIMP-2 and CEA tissue samples from colorectal liver metastases. Tumour Biol 2007; 28(5):247-252.

169. Oshima T, Kunisaki C, Yoshihara K, et al. Clinicopathological significance of the gene expression of matrix metalloproteinases and reversioninducing cysteine-rich protein with Kazal motifs in patients with colorectal cancer: MMP-2 gene expression is a useful predictor of liver metastasis from colorectal cancer. Oncol Rep 2008; 19(5):1285-1291.

170.Kim YW, Ko YT, Kim NK, et al. A comparative study of protein expression in primary colorectal cancer and synchronous hepatic metastases: the significance of matrix metalloproteinase- 1 expression as a predictor of liver metastasis. Scand J Gastroenterol 2010; 45(2):217-225.

171. Yamada $\mathrm{T}$, Oshima $\mathrm{T}$, Yoshihara $\mathrm{K}$, et al. Overexpression of MMP-13 gene in colorectal cancer with liver metastasis. Anticancer Res 2010; 30(7):2693-2699. 